\title{
Establishment and distribution of exotic biological control agents for silverleaf whitefly in Puerto Rico ${ }^{1,2}$
}

\author{
Alberto Pantoja ${ }^{3}$, Matthew A. Ciomperlik ${ }^{4}$, Leyinska Wiscovitch ${ }^{5}$, \\ Norberto Gabriel ${ }^{6}$, Pedro Vázquez $z^{7}$ and Wilfredo Robles ${ }^{8}$
}

J. Agric. Univ. P.R. 89(1-2):67-73 (2005)

\begin{abstract}
The establishment and distribution of exotic biological control agents for the silverleaf whitefly in Puerto Rico was evaluated. Five hundred thirty parasitoids were recovered from 99 sample sites. Encarsia spp. represented over $90 \%$ of the total samples profiled, whereas Eretmocerus spp. represented only $9.5 \%$. Eretmocerus hayati, from Pakistan, represented $56 \%$ of the total of that genus, followed by Er. mundus from Spain (38\%). An Encarsia sophia species from Pakistan was the most abundant, representing $29.6 \%$ of the total number of specimens from that group and $26.8 \%$ of the total number of specimens recovered during the study. Five unidentified, and possibly undescribed, species from Puerto Rico were detected during the study. Two of the local species represent about $23 \%$ of the total number of specimens collected.
\end{abstract}

Key words: whitefly, biological control, Eretmocerus, Encarsia

\section{RESUMEN}

Establecimiento y distribución de controladores biológicos de la mosca blanca en Puerto Rico

Se estudió la distribución y establecimiento de controladores biológicos de la mosca blanca en Puerto Rico. Quinientos treinta parasotoides se recuperaron de 99 lugares de muestreo. El género Encarsia spp. representó sobre el $90 \%$ de las muestras estudiadas, mientras que el género Eretmocerus spp. representó solamente el $9.5 \%$. La especie Eretmocerus hayati, de $\mathrm{Pa}$ kistán, representó el $56 \%$ del total para ese género, seguido de Er. mundus, importado de España (38\%). En el estudio, la especie Encarsia sophia pro-

${ }^{1}$ Manuscript submitted to Editorial Board 10 June 2004.

${ }^{2}$ The authors recognize comments on an earlier version of this manuscript by Dennis Fielding and Jeff Conn, USDA-ARS, Fairbanks, Alaska. Financial support was provided by the National Biological Control Institute (NBCI) Award no 99-8100-0540-GR.

${ }^{3}$ Entomologist, Department of Crop Protection, University of Puerto Rico-Mayagüez Campus. Current Address: USDA-ARS, University of Alaska, Fairbanks, P.O. Box 757200 , Fairbanks, AK 99775.

${ }^{4}$ USDA-APHIS-PPQ, Mission Biological Control Center, P.O. Box 2140, Mission, TX 78573-2140.

5USDA-APHIS-PPQ, 654 Plaza, Suite 700, Muñoz Rivera Ave, San Juan, PR 00918.

${ }^{6}$ USDA-APHIS-PPQ, P.O. Box 37521, San Juan, PR 00928.

${ }^{7}$ DHS CBP AI, La Puntilla \#1, San Juan, PR 00901.

${ }^{8}$ Department of Crop Protection, University of Puerto Rico-Mayagüez Campus. 


\begin{abstract}
veniente de Pakistán fue la más abundante de su género, con un $26.6 \%$ de los especímenes para ese grupo y $26.8 \%$ del total de especímenes. Cinco especies de Encarsia, probablemente especies nuevas de Puerto Rico, se detectaron durante el estudio. Dos de las especies nuevas representaron aproximadamente el $23 \%$ del total de especímenes estudiados.
\end{abstract}

Palabras clave: mosca blanca, control biológico, Eretmocerus, Encarsia

\title{
INTRODUCTION
}

Silverleaf whitefly Bemisia argentifolii Bellows \& Perring, former strain B of Bemisia tabaci (Gennadius), is a key pest insect of vegetables, field crops, and ornamental crops (Byrne et al., 1990; IFAS, 2003; Bemisia Newsletter, 2003; Mau and Lee, 2003). Damage results from plant debilitation, sooty mold growth, irregular ripening in tomato, and transmission of various geminiviruses (Schuster et al., 1992, 1993; Stansly et al., 1991, 1994; Naranjo, 2003; Naranjo et al., 1998; Bemisia Newsletter, 2003). In Puerto Rico, Bastidas et al. (1998) and Pantoja et al. $(1998,1999,2001)$ studied the combined effects of whitefly and associated geminiviruses.

Growers have had limited success combating silverleaf whitefly through intensive use of broad-spectrum insecticides, but systemic insecticides are available. However, chemical control is not a viable option for most Caribbean farmers because of low crop prices combined with the high cost of products and spray equipment, not to mention lack of expertise in handling toxic insecticides. Reliance on chemical control incurs economic, environmental and health costs and may cause resurgence and secondary pest outbreaks through decimation of natural enemies. Furthermore, resistance of $B$. argentifolii to some of the most commonly used insecticides suggests that efficacy may be of limited duration. Clearly, alternative management strategies are required.

Heavy use of broad-spectrum insecticides has aggravated the whitefly problem and selected for resistant populations (Byrne et al., 1990). It appears that biological control of this pest will function where broadspectrum insecticides are absent and habitat diversity provides a continuous source of hosts to maintain natural enemy populations (Schuster et al., 1992; Stansly et al., 1991, 1994). In an effort to prevent losses resulting from whitefly presence the USDA APHIS PPQ and the University of Puerto Rico cooperatively implemented a biological control program to control silverleaf whitefly. The biological control program included both classical and augmentative approaches (Gabriel and Vázquez, 1999; Ciomperlik et al., 1998, 2000). The objective of this work was to evaluate the establishment and distribution of exotic biological control agents of the silverleaf whitefly in Puerto Rico. Biological control is considered to be one of the most critical compo- 
nents of integrated pest management systems for sweet potato whitefly in the USA and throughout the world (Naranjo et al., 1998).

\section{MATERIALS AND METHODS}

From 26 May 1996 to 10 February 2000, the USDA/APHIS/PPQ laboratory in Mission, Texas, and the USDA APHIS PPQ office in San Juan, Puerto Rico, have released approximately 1.2 million parasitoids in 179 releases at 30 locations throughout Puerto Rico (Gabriel and Vázquez, 1999; Ciomperlik et al., 1998, 2000) (Figure 1). The species released and country of origin include Encarsia formosa (Greece \& Egypt); Encarsia sophia (= transvena) (Pakistan, India, Malaysia); Eretmocerus mundus (Spain); Er. hayati (Pakistan); Er. emiratus (United Arab Emirates); Eretmocerus spp. (Ethiopia).

Recovery studies were initiated in late November 1999 to determine establishment and current distribution of the parasitoids released in this collaborative effort. All samples were collected at least 24 months after the release date. Ninety-nine of the original 179 release sites were revisited and sampled. Sampling consisted of collecting foliage material infested with whitefly nymphs. Foliage was placed inside a plastic bag provided with a dry paper towel, and transported to the laboratory for emergence of the adult parasitoids. Data on farmer's name and site

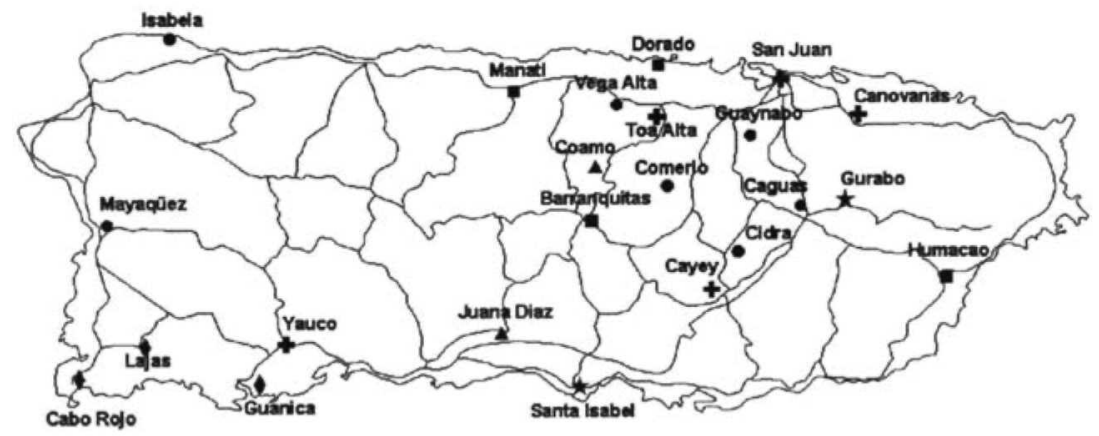

Release Sites and Totals
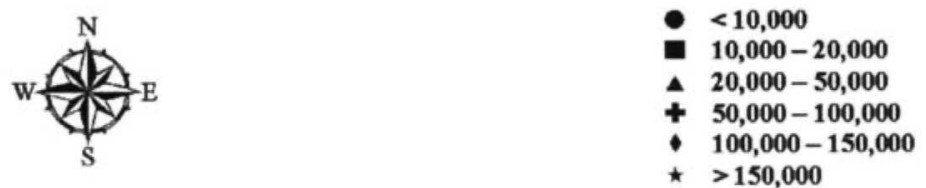

FIGURE 1. Site locations and release rates of exotic silverleaf whitefly parasitoids released in Puerto Rico, May 1996 to February 2000. 
coordinates were collected. In the laboratory, leaves were inspected and predators (spiders, lady bugs and others) were removed. Clean leaves were placed in $150-\times 25$-mm petri dishes provided with a paper filter. Dishes were arranged in trays and left at room temperature for 15 days. At the end of a 15-day waiting period, dishes were inspected under a stereomicroscope to detect parasitoid emergence. Parasitoids were placed in $90 \%$ ethyl alcohol and shipped to the USDA APHIS PPQ Mission Biological Control Center (MBCC) in Texas for morphological and genetic identification. Specimens were initially separated by genus and then genetically profiled by RAPD-PCR using the OPC-04 primer (Vacek et al., 1996; Ciomperlik et al., 2000).

\section{RESULTS AND DISCUSSION}

A total of 530 specimens were recovered from 99 sites. Genetic profiles allowed for species identification (Ciomperlik et al., 2000). Encarsia spp. represented $90.5 \%$ of the total sample collected, whereas Eretmocerus spp. represented only 9.5\%. Three species of Eretmocerus were recovered: Er. hayati, a species from Pakistan, accounted for 56\% of the recovered parasitoids of that genus and $5.3 \%$ of all specimens, followed by Er. mundus from Spain (38\% and 3.6\%) and Eretmocerus spp. from Taiwan (6\% and 0.6\%). In Spain, the fecundity of Er. mundus on pepper is high, thus suggesting this species might be a promising biological agent for the whitefly (Urbaneja et al., 2003). Three of the species released, Encarsia formosa from Egypt, Eretmocerus emiratus from the United Arab Emirates, and Eretmocerus spp. from Ethiopia, were not recovered during the study.

Encarsia sophia from Pakistan was the most abundant, representing $29.6 \%$ of the total number of specimens from that group and $26.8 \%$ of the total number of specimens recovered during the study (Table 1). Fourteen percent of the total number of specimens was represented by En. sophia from India. Five unidentified, and probably undescribed, species from Puerto Rico were detected during the study. Two of the local species, identified as patterns PR-A and PR-B (Table 3 ) represent 12.3 and $10.8 \%$, respectively, of the total number of specimens profiled. The Encarsia sp. (Parvella group), which was about $6.6 \%$ of the sample, is most likely endemic to the Caribbean; it was collected from Azua in the Dominican Republic in 1995 (Goolsby et al., 1998). Reconciliation of data records, indicating the initial release and the recovery site, reveals that exotic parasitoids were recovered three years after the initial liberation. This finding suggests that the parasitoids have become established on the island. The data also indicate that a local fauna of Encarsia represented by five species is present on the island. 
TABLE 1.-Encarsia (En.) species collected for silverleaf whitefly in Puerto Rico, 19992001.

\begin{tabular}{|c|c|c|c|c|}
\hline \multirow[b]{2}{*}{ Species } & \multirow[b]{2}{*}{ Origin } & \multirow[b]{2}{*}{$\mathrm{n}$} & \multicolumn{2}{|c|}{ Percentage of } \\
\hline & & & Specimens & Encarsia spp. \\
\hline En. sophia & India & 75 & 14.0 & 15.6 \\
\hline En. formosa & Greece & 2 & 0.4 & 0.6 \\
\hline En. spp. & Taiwan/Texas & 5 & 1.0 & 1.0 \\
\hline En. spp. & Taiwan/Pakistan & 1 & 0.2 & 0.2 \\
\hline En. sophia & Pakistan & 142 & 26.8 & 29.6 \\
\hline En. sophia & Malaysia & 21 & 4.0 & 4.4 \\
\hline En.sp. (Parvella gp) & Dominican Republic & 32 & 6.1 & 6.6 \\
\hline PR-A2PR-A ${ }^{1}$ & Puerto Rico & 65 & 12.3 & 13.4 \\
\hline PR-B2PR-B ${ }^{1}$ & Puerto Rico & 57 & 10.8 & 11.8 \\
\hline PR-C2PR-C1 & Puerto Rico & 12 & 2.3 & 2.5 \\
\hline PR-D2PR-D ${ }^{1}$ & Puerto Rico & 2 & 0.4 & 0.4 \\
\hline PR-E2PR-E ${ }^{1}$ & Puerto Rico & 7 & 1.3 & 1.5 \\
\hline Unknown & Puerto Rico & 15 & 2.8 & 3.2 \\
\hline
\end{tabular}

${ }^{1} \mathrm{PR}=$ Puerto Rico, unknown species, possibly undescribed species.

The native parasitoid fauna of Puerto Rico has not been well established; however, the predominant parasitoids collected during prerelease field sampling indicated that one Eretmocerus species is present but is less numerous than the native species of Encarsia (M. Ciomperlik, unpublished data). From pre-release evaluations, it was clear that the native parasitoid complex was not well suited to utilize Bemisia argentifolii as a host. After the release of the exotic Encarsia and Eretmocerus species, growers have indicated that whitefly pressures have been less severe, that yields have increased, and insecticide use has been reduced (Pantoja et al., 1998, 1999), thus suggesting the exotic parasitoids are regulating the pest. The data indicate that the exotic parasitoids have become established.

An Integrated Pest Management (IPM) program was implemented on a large tomato farm on the island. The IPM program combined the use of barrier crops, refuge crops and the liberation of Eretmocerus spp. and Encarsia spp. provided by the MBCC. The parasitoids were established in the farmer's field. After two years, the savings associated with the reduction of insecticide use by augmenting natural enemies is estimated to exceed $\$ 486 /$ ha (Pantoja et al., 1998; 1999). Unfortunately the price for tomatoes, not the ecological implications, is the key factor in determining the use of hard chemicals. If the price of tomatoes goes up, the use of hard chemicals replaces the use of natural enemies.

The establishment of the exotic parasitoids, however, has benefited small farmers who produce tomatoes for the local market and do not 
rely on export markets. The establishment of the exotic parasitoids has affected the whitefly populations in other crops such as ornamentals, beans, and eggplant (Pantoja et al., 1998, 1999). These studies lead to a better understanding of $B$. argentifolii parasitoids and their role in biological control programs. Additional work is needed to determine the predominant $B$. argentifolii parasitoids, to determine the native species of Eretmocerus, and to identify the native species of Encarsia detected in this survey.

\section{LITERATURE CITED}

Bemisia newsletter, 2003, http://www.tropicalwhiteflyipmproject.cgiar.org/wf/bemisia newsletter11.jsp\#6

Bastidas, H., A. Pantoja, M. Ciomperlik and L. Wiskovitch, 1998. Integration of biological control into management whiteflies on tomato in Puerto Rico. Proceedings Second Int. Workshop on Bemisia and Geminiviral Diseases, 7-8 June, 1998, San Juan, PR.

Byrne, D. N., T. S. Bellows, Jr. and M. P. Parrella, 1990. Whiteflies in agricultural systems. In: Whiteflies: their bionomics, pest status and management, D. Gerling (ed.). Intercept Ltd. Andover.

Ciomperlik, M., P. Vázquez, N. Gabriel and L. Wiscovitch, 1998. A classical biological control program against silverleaf whitefly in Puerto Rico. International Workshop on Bemisia and Gemini-viruses, 7-12 June 1998, San Juan, PR.

Ciomperlik, M., A. Pantoja, L. Wiscovitch, N. Gabriel and P. Vázquez, 2000. The biological control program against Silverleaf Whitefly in Puerto Rico. Programa Cooperativo Centroamericano para el Mejoramiento de Cultivos y Animales, 1-5 May 2000. San Juan, PR.

Gabriel, N. and P. Vázquez, 1999. Bemisia tabaci biocontrol project. Proceedings Fourth International Caribbean Conference of Entomology \& Florida Entomological Society, 25-29 July 1999. San Juan, PR.

Goolsby, J. A., M. A. Ciomperlik, B. C. Legaspi, Jr., J. C. Legaspi and L. E. Wendel, 1998. Laboratory and field evaluation of exotic parasitoids of Bemisia tabaci (Gennadius) (Biotype 'B') (Homoptera: Aleyrodidae) in the Lower Rio Grande Valley of Texas. Biological Control 12:127-135.

IFAS, 2003. Bemisia tabaci (Gennadius) or Bemisia argentifolii Bellows \& Perring (Insecta: Homoptera: Aleyrodidae), http://creatures.ifas.ufl.edu/veg/leaf/silverleaf_ whitefly.htm

Mau. R. F.L. and S.G. Lee, 2003. Bemisia argentifolii (Bellows and Perring). http:/ www.extento.hawaii.edu/kbase/Crop/Type/b_tabaci.htm

Naranjo, J., 2003. Overview of biological control programs for Bemisia in the USA with emphasis on Arizona. http://www.nal.usda.gov/ttic/tektran/data/000008/11/000008 1110.html

Naranjo, S. E., P. C. Ellsworth, C. C. Chu, T. J. Henneberry, D. G. Riley, T. F. Watson and R. L. Nichols, 1998. Action thresholds for the management of Bemisia tabaci (Homoptera: Aleyrodidae) in cotton. J. Econ. Ent. 91: 1415-1426.

Pantoja, A., H. Bastidas, I. Cabrera, C. Torres and P. Stanley, 1998. Effect of plant associations on management of the whitefly in commercial tomatoes in Puerto Rico Proceedings Second Int. Workshop on Bemisia and Geminiviral Diseases, 7-8 June 1998, San Juan, PR.

Pantoja, A., I. Cabrera, H. Bastidas and P. Stansly, 1999. Refuge crops enhance whitefly IPM. Biocontrol News and Information 20(4): 113-114. 
Pantoja, A., M. A. Ciomperlik, N. Gabriel, P. Vázquez, L. Wiscovitch and W. Robles, 2001. Evaluation of the establishment and distribution of exotic biological control agents of silverleaf whitefly in Puerto Rico. Proceedings Silverleaf Whitefly Conference, San Diego, CA.

Schuster, D. J., J. E. Polston and J. F. Price, 1992, Reservoirs of the sweet potato whitefly for tomatoes in west-central Florida. Proc. Fla. State Hort. Soc. 105:311-314.

Schuster, D. J., P. A. Stansly, D. G. Dean, J. E. Polston and G. S. Swanson, 1993. Progress toward a more sustainable pest management program for tomato. Proceedings of Florida Tomato Institute, C. S. Vavrina (ed.), University of Florida-IFAS, Gainesville, pp. 54-73.

Stansly, P. A., D. J. Schuster and G. L. Leibee, 1991. Management strategies for the sweetpotato whitefly. Proceedings Florida Tomato Institute, C S. Vavrina (ed.), Vegetable Crops Special Series SS-VEC-001, IFAS, Univ. of Florida, Gainesville, 1991, pp. 20-42.

Stansly, P. A., D. J. Schuster and H. J. McAuslane, 1994. Biological control of silverleaf whitefly: An evolving sustainable technology. In: Environmentally Sound Agriculture: Proceedings of the Second Conference, Orlando, FL., Am. Soc. Ag. Engineers, St. Joseph, MI, pp. 484-491.

Urbaneja, A., P. Stansly, D. Beltrán, J. Klapwijk and K. Bolckmans, 2003. Biological control of the whitefly Bemisia tabaci in Spain. http://www.whitefly.org/KoppertBS.htm

Vacek, D. C., R. A. Ruiz and L. E. Wendel, 1996. RAPD-PCR identification of natural enemies of SPWF. Proc. 4th Annu. Prog. Rev. 5-Yr. Nat. Re. Action Plan Dev. Mgmt. Contrl. Meth. Silverleaf Whitefly, 4-6 Feb. 1996, San Antonio, TX. P 139. 


\section{BLANK PAGE USED IN PAGE COUNT}

